\title{
An Empirical Analysis of the Buyer's Perspective of Gaining Competitive Advantage through Supplier Development
}

\author{
Amir Manzoor * $\quad$ Naveed R Khan ${ }^{\dagger} \quad$ Khurram Adee ${ }^{\ddagger}$
}

\begin{abstract}
This study analyzes how buyer firm's supplier development efforts can help achieve buyer's competitive advantage. The main goal of this analysis is to understand how various supplier development efforts could impact the operational performance of a buyer. The study used the survey responses from consumer electronic businesses in Karachi. The study developed a model and used these responses to test hypothesized relationships among various dimensions of supplier development and buyer's competitive advantage. The study found that the two most significant factors affecting competitive advantage and operational performance of buyer were joint actions and trust. The study provides important implications regarding supplier development and buyer competitive advantage for both supply chain managers and academicians.
\end{abstract}

Keywords: Supplier development, market responsiveness, operational effectiveness, competitive advantage, joint action, asset specificity, performance expectations, trust.

\section{Introduction}

The term supply chain means the network of activities starting from the suppliers end till the customers end. The start of any activity generally starts from the natural sources. We can say that it consists of activities from the upstream channel members to the downstream channels members. It can be understood from an agricultural product example, which starts from the seed supplier that supplies provide seeds to the farmer who uses these seeds for agricultural product sowing and then supply this product to the manufacturer. The manufacturer, after production of the finished product, supplies it to the distributor. Distributor sends the products to the wholesaler who in turn sends the products to the retailer from the customer finally have the product. This was the simple example of activities starting from the upstream channel members until the downstream channel members. Supply chain can also be viewed as a network from the tears of suppliers to the tears of customers or network of inbound logistics to outbound logistics. Per APICS (American Production and Inventory Control Society), it is a worldwide network exercised to deliver products and services from raw material suppliers to end consumers by anarchistic run of information and cash. Basic supply chain model consists of three parties which are

\footnotetext{
*Bahria University - Karachi Campus Management Sciences. E-mail: amirmanzoor@yahoo.com

${ }^{\dagger}$ Bahria University - Karachi Campus Management Sciences. Email: naveed.r.khan@gmail.com

‡Bahria University - Karachi Campus Management Sciences Karachi Pakistan.

Email: khurramadeel.bukc@bahria.edu.pk
} 
supplier, producer, and customer with three mandatory flows of physical product flow, information flow (communicating specifications) and cash flow and reverse product flow which consists of defectives/repaired items, recalls, refilling and recycling. Supply Chain Management (SCM) as per APICS is the designing, planning, implementing, monitoring, and controlling of all supply chain activities with the purpose of creating value, building worldwide system to move and positioned the inventory, building a strong infrastructure as compared to competitors, matching of supply with the demand and assessing the performance globally.

According to Krause (1997); Ellram and Krause (2014) supplier development refers to buyer's efforts to increase supplier's performance and capabilities. The prime objective buyers would like to achieve through supplier development is fulfillment of their own supply needs. The main goal of this study is to analyze how various supplier development initiatives could affect the buyer's competitive advantage. During the last decade,manufacturing firms are increasingly paying attention to the performance of their supply chains. Suppliers are a vital and important part of any supply chain. An increasing number of manufacturing firms are realizing the significant performance of their suppliers in order to establish and sustain competitive advantage (Peters, Hofstetter, \& Hoffmann, 2011; S. Li, Rao, RaguNathan, \& Ragu-Nathan, 2005). The literature on supply chain has started to focus on supplier development initiatives and its effect on buyer and supplier performance (Goffin, Lemke, \& Szwejczewski, 2006; Monczka, Trent, \& Callahan, 1993). Many studies (Hahn, Watts, \& Kim, 1990; Gunasekaran \& Ngai, 2005) have shown that implementing effective supplier development initiatives results in enhanced buyer and supplier performance.

The important question here is which specific supplier development initiatives can provide unique contribution to the competitive advantage of buyer. Literature points out many supplier development initiatives. These include raising performance goals for suppliers (S. Li et al., 2005); supplier training (Liu, Zhang, Hendry, Bu, \& Wang, 2018); supplier support initiates (including equipment, technology, investments) (Monczka et al., 1993; Liu et al., 2018); buyer-supplier inter-firm human resource exchange (Newman \& Rhee, 1990; Graca, Barry, \& Doney, 2015); supplier performance assessment (Giunipero, 1990; Terpend \& Krause, 2015); and supplier reward schemes (Galt \& Dale, 1991; Curkovic, Vickery, \& Dröge, 2000).

Many research studies provide extensive discussion of the issues related to establishing of supplier development plans including the features, advantages, and supervision of such programs (Liker \& Choi, 2004; Ellram \& Krause, 2014), the necessity of buyer firm's involvement in supplier development, mechanism of developing supplier development programs, and expected benefits to be obtained from supplier development initiatives (Reed \& Walsh, 2002; Routroy \& Pradhan, 2014; Goffin et al., 2006).

While existing literature does provide support to the notion that supplier development does help buyer achieve and sustain competitive advantage (Hahn et al., 1990; Monczka et al., 1993; Burt, Dobler, \& Starling, 2003), it does not inform which are the specific supplier development initiatives that buyer firms could focus on and that would ultimately result in competitive advantage of buyer (Soares, Soltani, \& Liao, 2017; Robinson \& Malhotra, 2005). In addition, there is limited literature that provides empirical examination of supplier development initiatives and its impact on buyer's competitive advantage in the 
context of developing countries. The major objective of this study is to empirically examine the relationship between supplier development initiatives and competitive advantage of buyer.That examination could help predicting the buyer's competitive advantage in the context of emerging countries.

This research begins with a comprehensive review of supplier development literature.A conceptual model is then developed that links supplier development initiatives with buyer's completive advantage. The model is then tested; results are presented, and analyzed. To conclude, the study discusses research implications and areas of future research.

\section{Review of Literature}

Literature provides ample support to the notion that buyer firms can enhance their performance by focusing on development of their suppliers (Sakita, 2016; Saeki \& Horak, 2014). Utilizing the resources-based view, (Barney, 1991)argued that firms gain competitive advantage when they have resources and capabilities that are valuable, heterogeneous, and immobile. Supplier development refers to buyer's actions aimed at enhancing competitive capability of its suppliers. The distinctive give-and-take relationships between buyer and supplier become the unique resource/capability of the buyer that can help buyer achieve and sustain competitive advantage.

Economists have long held the idea that, through cooperative relationships, resource owners can increase their productivity (Low \& Ho, 2016; Alchian \& Demsetz, 1972). According to Schmalensee, Armstrong, Willig, and Porter (1989), asset-specific investment can provide trading partners increased gains from trade. According to Dyer (1996) and (Pulles, Veldman, \& Schiele, 2014), a firm can enhance its efficiency by creating specialized assets in conjunction with its trading partners. Since supplier development programs are relations-specific programs, the buyer expects to gain competitive advantage by transforming its general assets into specific resources/capabilities (Filippini \& Forza, 2016; De Toni \& Nassimbeni, 2000; W. Li, Humphreys, Yeung, \& Cheng, 2007).

Still, cost incurs to achieve specialization within a production network. Fear of opportunism results in increased transaction costs when Buying firms make specialized investments. This increase is because specific assets require more complex control structures. These complex structures are needed to gain good bargaining position when dealing with a supplier having specialized assets and in a much strong bargaining position (Williamson, 2007).

Dyer (1996) found that Japanese buying firms in automobile sector made greater assetspecific investments and were able to achieve superior performance. This finding is not surprising. Asanuma (1989); Saeki and Horak (2014), in their study of Japanese manufacturing firms, found that buyers and supplier maintained very close relationships. One important finding was that transaction costs of Japanese buying firms were significantly lower compared to their US counterparts. This suggests that firms can gain competitive advantage by simultaneously increasing their asset specificity while lowering transaction costs. A greater understanding of achievement of this dual benefit could shed more light onto the process of developing the collaborative relationships between buyer and supplier. 


\section{Supplier Development}

There are numerous initiatives buyer firms can take to improve capabilities and performance of their suppliers. Broadly, these initiatives can be divided into following categories.

\section{Asset Specificity}

Asset specificity refers to the transaction-specific investments that a buying firm makes in its supplier (Krause \& Ellram, 1997). This includes direct and supplier-specific investment of buyer in human or physical assets. Some of these investments may include investments into customized equipment and tools, technical support and training (W. Li et al., 2007). Dyer (1996); Pulles et al. (2014) argues that these specific investments could encourage suppliers to customize their products for customers. This could result in reduced procurements costs, reduces product development life cycle, and more effective communication between supplier and customers.

\section{Joint Action}

It refers to in-depth buyer-supplier cooperation. This cooperation covers significant activities needed for mutual improvement of performance oof both parties (i.e. buyer and seller). One example is the buyer's participation in operations management of supplier. Another example is supplier assistance in product development process of buyer firm.Close buyer-supplier relationships can result from increased scope of joint activities (Heide \& John, 1990).

\section{Performance Expectation}

It refers to what performance improvements buyers expect from their suppliers (Krause \& Ellram, 1997). One way to motivate suppliers is to increase their performance goals (Lascelles \& Dale, 1989). Rewards for supplier performance improvement can be considered market-based incentives. These rewards are intended to encourage suppliers to increase their performance level.

\section{Trust}

With increase in its transaction-specific investments on a particular supplier, the buyer tends to develop a more close and dependent relationship with this supplier while exposing itself to larger risk and uncertainty levels (Krause, 1997). According to Williamson (2007), buyers must take measures to secure their transactions from the propensity of opportunism of their suppliers. One such important measure is contracts (Dyer, 1996; Pulles et al., 2014). Another but more effective and less costly way to safeguard these transactions. In addition, when buyer's trust on supplier increases the probability of joint action between buyer and supplier increases. 


\section{Buyer's Competitive Advantage}

The buyer's competitive advantage comes in two important form: Operational Effectiveness and Market Responsiveness.

\section{Operational Effectiveness}

Researchers S. Li et al. (2005); Clark (1996); Hayes and Wheelwright (1984) held the view that to gain competitive advantage, buyer firms need to develop high quality products/services while minimizing their costs. As such, high quality and minimization of costs are considered important indicators of operational effectiveness of a buyer firm.

\section{Figure 1}

Conceptual Model

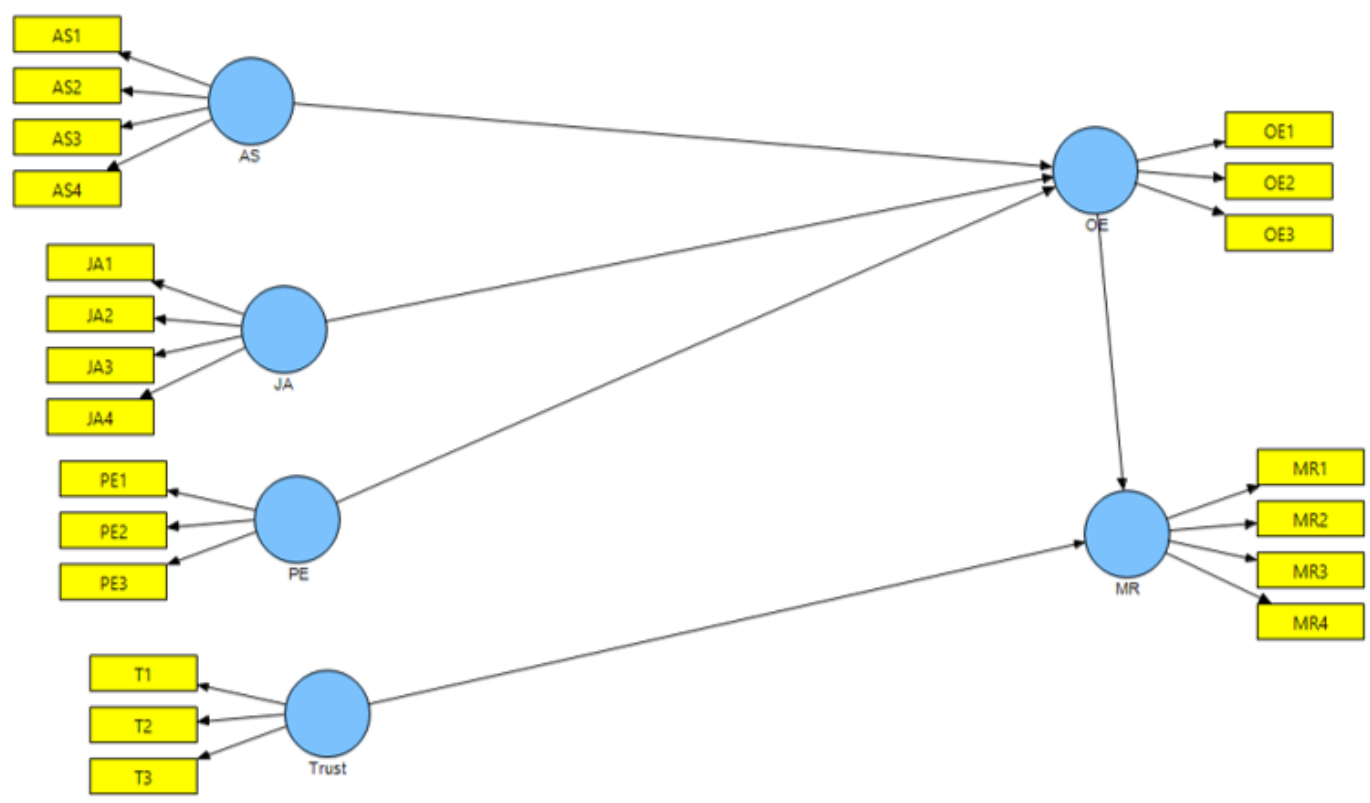

\section{Market Responsiveness}

Researchers Nidumolu and Knotts (1998) suggest that another important source of competitive advantage of buyer firms is market responsiveness. Market responsiveness can enable buyer firms to compete effectively in this era of intensified, global competition. Harmsen, Grunert, and Bove (2000) found in his study of managers of buyer firms, that managers considered market responsiveness as second most important core competency of a firm. Figure 1 shows the conceptual model used in this study. This model postulates that each initiative for supplier development results in improvement of buyer's competitive advantage (Wagner, Fillis, \& Johansson, 2005; Hartley \& Choi, 1996; Monczka et al., 
1993).

We analyzed all of the path linkages in our conceptual model (Figure 1) forming specific hypotheses for every path. The theoretical basis for the conceptual model was The following hypotheses were formulated.

$H_{1}$ : There is a direct relationship between asset specificity and operational effectiveness.

$\mathrm{H}_{2}$ : There is a direct relationship between joint action and operational effectiveness.

$H_{3}$ : There is a direct relationship between performance expectation and operational effectiveness.

$H_{4}$ : There is a direct relationship between trust and market responsiveness.

$H_{5}$ : There is a direct relationship between operational effectiveness and market responsiveness.

\section{Research Methodology}

\section{Questionnaire}

Based on extensive literature review, a questionnaire was developed. This study utilized this questionnaire to collect data. The questionnaire consisted of multiple statements against each construct. The questionnaire included multiple scale items for each construct used in the conceptual model. Managers from five businesses were asked to provide help in pre-testing of the questionnaire. This was done to ensure readability, non-ambiguity, coverage of all possible responses for close-ended questions. Three professors from business schools were also consulted. These professors had expertise in supply and purchasing. These professors evaluated survey items for ambiguity and clarity and appropriateness of measures for their respective constructs. In the light of comments made by people involved in pre-testing, minor modifications were made in the questionnaire. The finalized questionnaire was then circulated among the participants.

\section{Sampling}

The data used in this study was collected using a self-administered questionnaire. A list of consumer electronics businesses was compiled. Out of 653 questionnaires sent, 349 usable responses were received thus achieving a response rate of $53 \%$.

Items used to estimate the predictor latent constructs were measured on a Ten- point Likert scale. The items used for each construct were derived from literature. A confirmatory factor analysis (CFA) was used to test the hypothesized model. Table 1 indicates the items used to estimate the predicted latent constructs (AS, JA, PE, and Trust), operational effectiveness, and market responsiveness. 


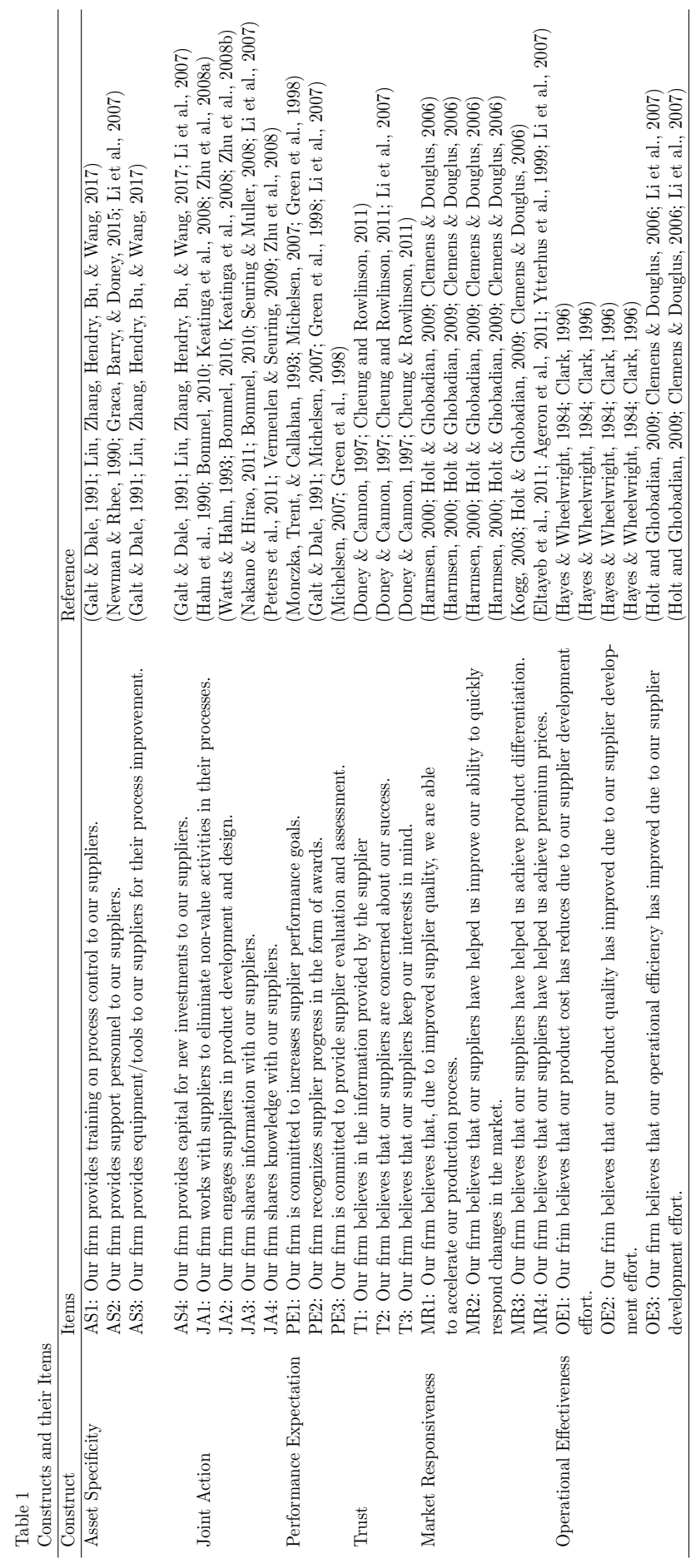




\section{Results}

The conceptual model developed in this study was analyzed using SmartPLS. Table 2 lists composite reliability results. To check the composite reliability of all constructs we calculated their composite reliabilities. The composite reliabilities of different constructs varied between 0.78-0.95. According to Leong, Ooi, Chong, and Lin (2011), in order establish composite reliability of a construct, the composite reliability value of a construct should be greater than 0.7. Fornell and Larcker (1981) suggested that, in order establish composite reliability of a measure, average variance extracted (AVE) for each measure exceeded 0.50. Based on these criteria, we can establish that all measures in our model are robust in terms of their internal consistency reliability.

Table 3 lists results of discriminant validity of various measures. In order establish discriminant validity of a measure, we need to check whether diagonal values in the matrix are greater than the off-diagonal elements in their corresponding row and column. The diagonal values represent the square roots of the AVEs. Looking at Table 3, we can see that this criterion is met for all measures. Therefore, we can establish validity of our measures used in this study.

Table 2

Assessment of the model

\begin{tabular}{lcccccc}
\hline & AVE & Composite Reliability & R Square & Cronbachs Alpha & Communality & Redundancy \\
\hline AS & 0.7352 & 0.9170 & 0.0000 & 0.8781 & 0.7352 & 0.0000 \\
JA & 0.6879 & 0.8981 & 0.0000 & 0.8501 & 0.6879 & 0.0000 \\
MR & 0.5895 & 0.8512 & 0.2958 & 0.7665 & 0.5895 & 0.1402 \\
OE & 0.5524 & 0.7868 & 0.3965 & 0.6022 & 0.5524 & 0.1050 \\
PE & 0.8790 & 0.9561 & 0.0000 & 0.9312 & 0.8790 & 0.0000 \\
Trust & 0.5722 & 0.8003 & 0.0000 & 0.6341 & 0.5722 & 0.0000 \\
\hline
\end{tabular}

Table 3

Discriminant validity (intercorrelations) of variable constructs

\begin{tabular}{lcccccc}
\hline & AS & JA & MR & OE & PE & Trust \\
\hline AS & 0.8574 & 0.0000 & 0.0000 & 0.0000 & 0.0000 & 0.0000 \\
JA & 0.4784 & 0.8293 & 0.0000 & 0.000 & 0.0000 & 0.0000 \\
MR & 0.2708 & 0.3007 & 0.7677 & 0.0000 & 0.0000 & 0.0000 \\
OE & 0.4976 & 0.5471 & 0.5024 & 0.7432 & 0.0000 & 0.0000 \\
PE & 0.3226 & 0.2357 & -0.0040 & 0.3420 & 0.9375 & - \\
Trust & 0.3717 & 0.4956 & 0.4292 & 0.4941 & 0.2449 & 0.7564 \\
\hline
\end{tabular}

In order establish the convergent validity of our measures, we extracted the factor and cross loadings of all indicator items to their respective latent constructs. These results are presented in Table 4. In order establish convergent validity, all items should load more highly on their respective construct than on any other construct. Looking at Table 4, we can see the item loading values range from 0.70 to 0.95 . All items were heavily on their respective construct. Each factor loading on its respective construct was highly significant as shown by t-value of each loading (see Figure 2). Looking at these statistics, we can establish the convergent validity of our measures. 
Table 4

Factor loadings and cross loadings

\begin{tabular}{lllllll}
\hline & AS & JA & MR & OE & PE & Trust \\
\hline AS1 & $\mathbf{0 . 8 4 0 1}$ & 0.4014 & 0.1908 & 0.3827 & 0.2478 & 0.273 \\
AS2 & $\mathbf{0 . 8 9 9}$ & 0.3922 & 0.2151 & 0.4251 & 0.3233 & 0.3258 \\
AS3 & $\mathbf{0 . 9 1 3 7}$ & 0.4282 & 0.2464 & 0.4493 & 0.3139 & 0.3274 \\
AS4 & $\mathbf{0 . 7 6 9 4}$ & 0.4142 & 0.2688 & 0.4403 & 0.2168 & 0.3404 \\
JA1 & 0.4188 & $\mathbf{0 . 8 4 2 9}$ & 0.2048 & 0.4579 & 0.17 & 0.4019 \\
JA2 & 0.4286 & $\mathbf{0 . 8 1 4 1}$ & 0.3263 & 0.5314 & 0.2207 & 0.4916 \\
JA3 & 0.3385 & $\mathbf{0 . 8 1 6 2}$ & 0.2593 & 0.3742 & 0.2086 & 0.3249 \\
JA4 & 0.3835 & $\mathbf{0 . 8 4 3 9}$ & 0.1913 & 0.421 & 0.1791 & 0.3949 \\
MR1 & 0.1539 & 0.1941 & $\mathbf{0 . 8 0 5 8}$ & 0.4306 & 0.0119 & 0.3071 \\
MR2 & 0.2025 & 0.1910 & $\mathbf{0 . 7 0 2 3}$ & 0.3106 & 0.0282 & 0.3142 \\
MR3 & 0.2216 & 0.2875 & $\mathbf{0 . 8 2 3 4}$ & 0.4208 & -0.0073 & 0.3551 \\
MR4 & 0.2581 & 0.2454 & $\mathbf{0 . 7 3 3 1}$ & 0.3696 & -0.0419 & 0.3431 \\
OE1 & 0.3108 & 0.3323 & 0.1953 & $\mathbf{0 . 6 8 6 9}$ & 0.2973 & 0.3371 \\
OE2 & 0.2643 & 0.3641 & 0.5984 & $\mathbf{0 . 7 5 2 6}$ & 0.0826 & 0.3892 \\
OE3 & 0.5194 & 0.5058 & 0.2801 & $\mathbf{0 . 7 8 6 7}$ & 0.3980 & 0.3733 \\
PE1 & 0.3031 & 0.2547 & 0.0216 & 0.3310 & $\mathbf{0 . 9 4 2 1}$ & 0.2556 \\
PE2 & 0.2914 & 0.1905 & 0.0271 & 0.3135 & $\mathbf{0 . 9 4 5 5}$ & 0.2374 \\
PE3 & 0.3128 & 0.2159 & -0.0611 & 0.3171 & $\mathbf{0 . 9 2 4 9}$ & 0.1948 \\
T1 & 0.3190 & 0.5498 & 0.3806 & 0.4686 & 0.1375 & $\mathbf{0 . 7 2 5 5}$ \\
T2 & 0.2732 & 0.2512 & 0.2867 & 0.3478 & 0.2005 & $\mathbf{0 . 7 8 9 4}$ \\
T3 & 0.2339 & 0.2592 & 0.2829 & 0.2666 & 0.2312 & $\mathbf{0 . 7 5 3 0}$ \\
\hline
\end{tabular}

Figure 2

Structural Model Results

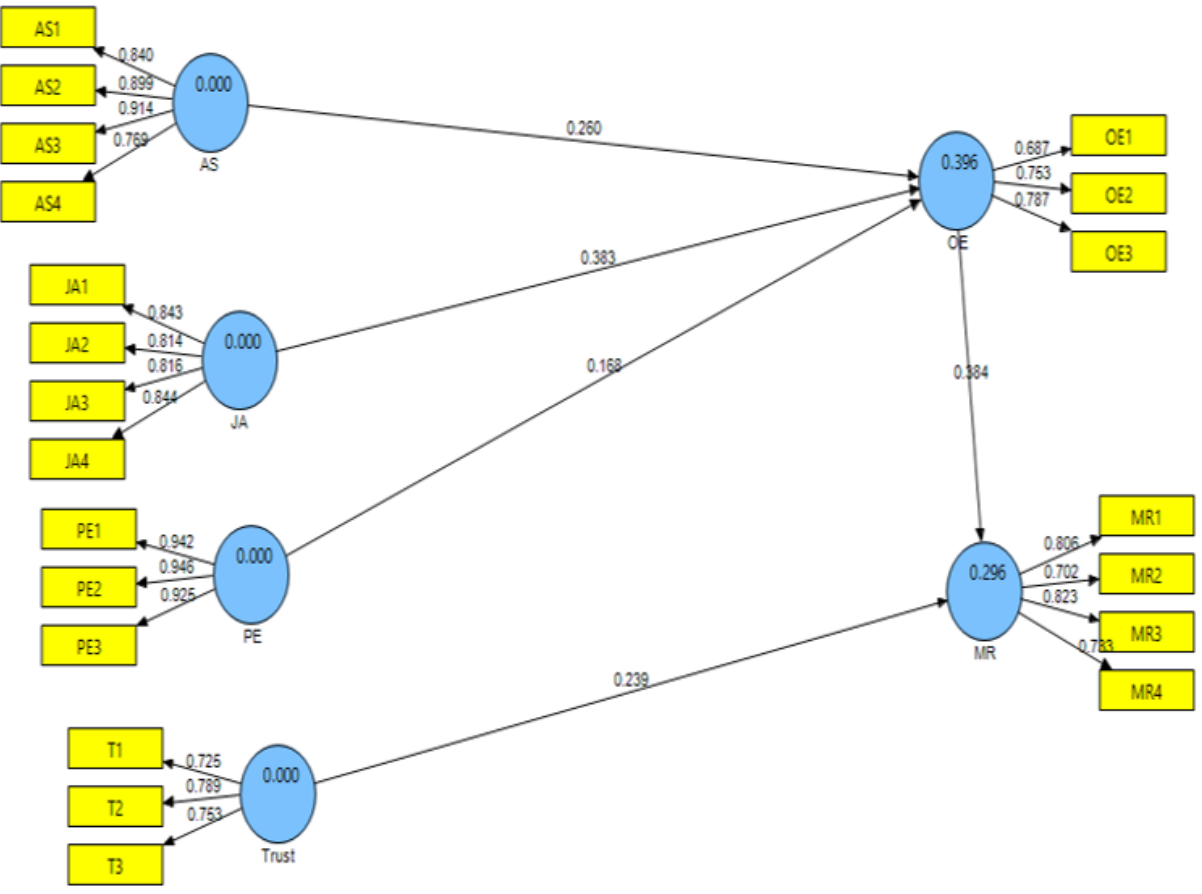




\section{Figure 3}

Conceptual Model-Significance of Constructs

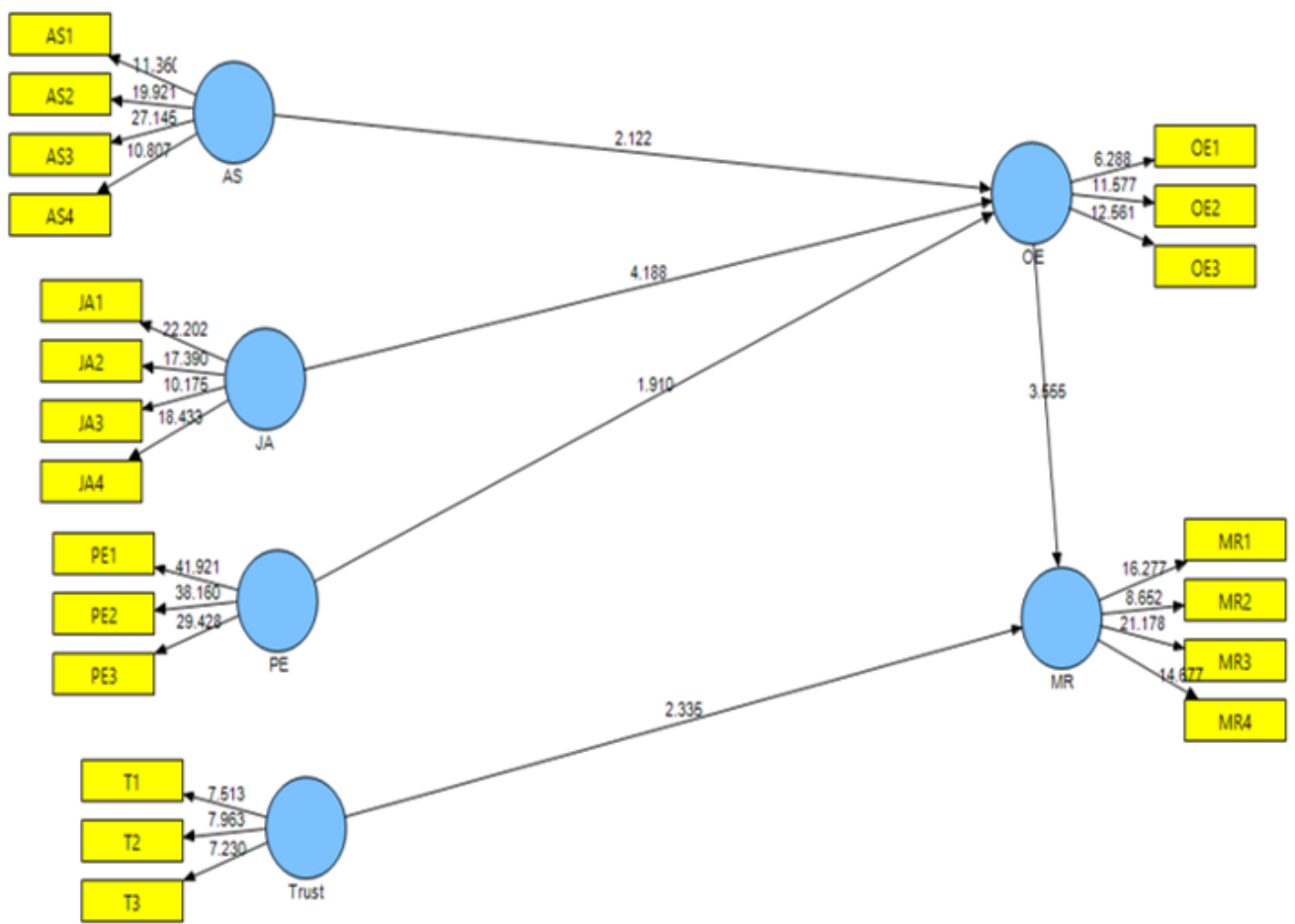

\section{Discussion}

Table 5 presents the hypotheses and outcomes.

Table 5

Hypotheses conclusions

\begin{tabular}{|c|c|c|}
\hline Hypotheses & Finding & Conclusion \\
\hline $\begin{array}{l}\text { H1: There is a direct relationship between asset } \\
\text { specificity and operational effectiveness. }\end{array}$ & Yes $($ beta $=0.260$, t-value $=2.122)$ & Supported \\
\hline $\begin{array}{l}\text { H2: There is a direct relationship between joint } \\
\text { action and operational effectiveness. }\end{array}$ & Yes $($ beta $=0.383, \mathrm{t}$-value $=4.188)$ & Supported \\
\hline $\begin{array}{l}\text { H3: There is a direct relationship between performance } \\
\text { expectation and operational effectiveness. }\end{array}$ & Yes $($ beta $=0.168, \mathrm{t}$-value $=1.910)$ & Not Supported \\
\hline $\begin{array}{l}\text { H4: There is a direct relationship between trust and } \\
\text { market responsiveness. }\end{array}$ & Yes $($ beta $=0.239$, t-value $=2.335)$ & Supported \\
\hline $\begin{array}{l}\text { H5: There is a direct relationship between operational } \\
\text { effectiveness and market responsiveness. }\end{array}$ & Yes $($ beta $=0.384, \mathrm{t}$-value $=3.555)$ & Supported \\
\hline
\end{tabular}

Figure 2 shows the results of conceptual model and the standardized regression weights. The t-values of various constructs are shown in Figure 3. Joint action and asset specificity 
have significant and positive impact on operational effectiveness of buyer. Performance expectation has positive but non-significant impact on operational effectiveness of buyer. In addition, trust has significant and positive impact on market responsiveness.

In this study, we developed and tested a model that hypothesized relationships between different initiatives of supplier development and sources of buyer's competitive advantage. This model provided important information about how supplier development could affect buyer's competitive advantage. This model has also provided information about the relationship between the components of buyer's competitive advantage.

\section{Asset Specificity and Operational Effectiveness}

The results of analysis of conceptual model show that asset specificity has direct and positive impact on operational effectiveness. This finding is in support of previous studies. These studies suggest that high level of market responsiveness is an significant cause of competitive advantage (S. Li et al., 2005). Many studies (Dyer, 1996; W. Li et al., 2007) found that inter-firm asset specialization facilitates the ability of firms to improve their operational effectiveness. Williamson (2007) argued that a new supplier would be able to gain knowledge of exclusive technical and management procedures and task-specific labor skills. With this knowledge, supplier can subsequently perform tasks more quickly. Increased inter-firm human asset specificity can inform both buyer and supplier where the useful human resources reside in their respective firms. This relation-specific knowledge can help people at both firms gain substantial experience working together and there are less chances they will misinterpret information.Increased asset specificity ultimately results in less communication errors. This is because the feedback loop becomes more efficient. According to Buvik and Grønhaug (2000), this enhanced communication could provide faster product development and market responsiveness. This point was further supported by Cohen and Levinthal (1990) who found that with increased asset specificity both parties are in a better position to learn from each other's experiences.

\section{Joint Action and Operational Effectiveness}

This study found that joint action directly and positively impacts operational effectiveness. This result supports the work of previous researchers (Ellram \& Krause, 2014; Liker \& Choi, 2004; Womack, Womack, Jones, \& Roos, 1990). These researchers found that effective collaboration between customers and suppliers results in enhanced product quality and decreased cost of operations. Many research studies (Hayes \& Wheelwright, 1984; Clark, 1996) have argued that the critical objective of manufacturing concerns is to minimize cost while providing best quality products. Therefore, operational effectiveness means to pursue ways to achieve this objective. According to Clark (1996); Burt et al. (2003) quality of product can be enhanced by improving coordination in design and manufacturing. In order increase the reliability of the product, manufacturers need to give their suppliers more responsibility in the development of final product. Close buyer-supplier relationship can help buyer firms eliminate non-value added activities from their existing processes. According to Kulmala, Paranko, and Uusi-Rauva (2002), it could also help buyer firms to establish just-in-time delivery systems. These arrangements can provide mutual benefits 
for buyer and supplier because they can economize their operations costs (Dyer, 1996). Clark, Fujimoto, and Cook (1991) support this idea by suggesting that close linkages, both within buyer firm and with suppliers, can help manufacturing firms develop cost-efficient, high-quality products.

\section{Trust and Operational Effectiveness}

This study found that buyer's trust directly and positively influences operational effectiveness of the buyer. This finding was expected and in line with the findings of earlier studies that examined what role trust played in buyer-supplier relationships (Scannell, Vickery, \& Droge, 2000; De Toni \& Nassimbeni, 2000; Smeltzer, 1997). According to Anderson and Narus (1990); Narasimhan and Nair (2005), trust is considered to be a cost-efficient and more effective mean for buyer firms to protect their asset-specific investments, reduce conflict and enhance supplier satisfaction with buyers. Swan and Nolan (1985) argued that suppliers tend to facilitate and develop customer trust when they see their customers (buyer firms) are actively seeking more collaborative relationships. Cohen and Levinthal (1990) argues that, when parties trust each other, information provided by them is used more and considered more valuable. These parties recognize the value of shared information. They assimilate this shared information to improve quality of their products. Dyer (1996) further argues that greater the scope of information shared, greater the expected quality of the product. Dyer (1996) argue that collaborative relationships are established when both parties establish exchange relationships founded on higher levels of trust. With such collaborative relationships, both parties can focus on long-term benefits. According to Noordewier, John, and Nevin (1990), these collaborative relationships ultimately result in enhanced competitiveness and reduced transaction costs for both parties.

\section{Performance Expectation and Operational Effectiveness}

This study found that buyer's performance expectation from its suppliers has no direct and significant impact on operational effectiveness of buyer. This result was unexpected. Previous literature (S. Li et al., 2005; Krause \& Ellram, 1997) found that by raising supplier performance goals and rewarding performance improvement, buyer firms can motivate their suppliers to improve performance. According to (Monczka et al., 1993) buyer firms can only expect increased contribution from suppliers if they aggressively increase their performance expectations from suppliers. Krause (1997) further argues that buyer firms should only keep those suppliers that meet buyer's performance goals. Buyer firms should also recognize supplier's performance improvements by awarding them rewards (such as long-term contracts).

The some conflicting results of this study may be because of the particular industrial setting chosen for this study. In electronics industry of Pakistan, majority of businesses rely on short-term contracts with suppliers and dependent on supplier flexibility to respond to changing market conditions and customer demand. In addition, these businesses are unsure of their future prospects and consequently it is very difficult for them to reward their performing suppliers in terms of granting long-term contracts. For example, some businesses mentioned that customers are becoming very demanding with respect to cost 
and quality. Customers want high quality and low cost. Still, uncertain about their future prospects, businesses are unwilling to make long-term investment to cater the needs of specific customers. This also means that businesses should not press their supplier with tough performance objectives without long-term commitment. Otherwise, suppliers can get frustrated and will not feel confident in their performance. Therefore, buyer firms looking to improve performance of their suppliers should be cautious when developing supplier performance objectives. They need to make sure that, in absence of long-term commitment, their supplier performance expectations should be realistic and achievable by suppliers.

\section{Operational Effectiveness and Market Responsiveness}

This study found that operational effectiveness has direct and significant impact on market responsiveness. This finding supports the findings of previous studies. According to previous studies, low cost and high quality are important to achieve competitive advantage for manufacturing-based concerns. Since operations management aims to provide better products/services at minimum possible costs, better quality and minimization of costs are considered important factors of operational effectiveness (S. Li et al., 2005; Clark, 1996; Hayes \& Wheelwright, 1984). Various researchers (Harmsen et al., 2000), have argued that market responsiveness is also essential to achieve competitive advantage for businesses. In this context, it can be said that that enhanced operational effectiveness directly contributes to the increased level of market responsiveness of a firm.

\section{Conclusion}

This study provided a detailed investigation of the impacts of specific efforts of supplier development on buyer competitive advantage. The results suggest that different aspects of supplier development produce different impact on different aspects of buyer's competitive advantage and supplier development should take place while taking into consideration the expected benefits for the buyer. The study finds that, in general, supplier development efforts produce a positive impact on buyer's competitive advantage. The study found that joint action and trust were two most significant dimensions of supplier development that positively and significantly impacted the buyer's competitive advantage. As such, buyer firms should focus on establishing close collaboration with suppliers in their product design process and removal of non-value added activities from existing processes. Increased buyersupplier trust can not only provide a long-term mutually beneficial relationship but also reduce transaction costs for both buyer and supplier. This study also found that higher level of trust could help buyer firms enhance their operational effectiveness and its impact is strong. However, an increase in performance goals of supplier and recognition of their efforts appears not impact the competitive advantage of buyer firms. As such, buyer firms should exercise this aspect of supplier development with caution. Given that supplier development requires considerable resource, this study provides useful insights for both academicians and practitioners. 


\section{Limitations of Study and Future Research Areas}

Every study has some limitations and this study is no exception. First, this study was carried out in a single industrial setting. Though this study was able to provide accurate, context-specific measures, future studies may be conducted in different industrial settings to establish the nature of supplier development activities and to provide a better understanding of how different dimensions of supplier development may impact supplier performance and competitive advantage of buyer. More focus can be placed on those industries that are more important for Pakistan's economy. Second, this study used crosssectional data. Future studies could use longitudinal data to understand the impact of time on the nature of supplier development activities and its role in buyers competitive advantage. Third, future studies could use triangulation of research techniques, such as surveys, experiments, and qualitative methods to enhance the validity of the proposed model and extend the theory development. This multi-method approach could also serve to provide an improved framework of buyer-supplier relationships, converge research, and accumulate knowledge. Future studies could also be case studies that could focus on particular cases of buyer-supplier relationships and could shed more light on various aspects of supplier development strategies and their benefits. 


\section{References}

Alchian, A. A., \& Demsetz, H. (1972). Production, information costs, and economic organization. The American Economic Review, 62(5), 777-795.

Anderson, J. C., \& Narus, J. A. (1990). A model of distributor firm and manufacturer firm working partnerships. Journal of Marketing, 54(1), 42-58.

Asanuma, B. (1989). Manufacturer-supplier relationships in japan and the concept of relation-specific skill. Journal of the Japanese and International Economies, 3(1), $1-30$.

Barney, J. (1991). Firm resources and sustained competitive advantage. Journal of Management, 17(1), 99-120.

Burt, D. N., Dobler, D. W., \& Starling, S. L. (2003). World class supply management: The key to supply chain management. Irwin/McGraw-Hill.

Buvik, A., \& Grønhaug, K. (2000). Inter-firm dependence, environmental uncertainty and vertical co-ordination in industrial buyer-seller relationships. Omega, 28(4), $445-454$.

Clark, K. B. (1996). Competing through manufacturing and the new manufacturing paradigm: Is manufacturing strategy passé? Production and Operations Management, $5(1), 42-58$.

Clark, K. B., Fujimoto, T., \& Cook, A. (1991). Product development performance: Strategy, organization, and management in the world auto industry. Harvard Business School Press Boston, MA.

Cohen, W. M., \& Levinthal, D. A. (1990). Absorptive capacity: A new perspective on learning and innovation. Administrative Science Quarterly, 35(1), 128-152.

Curkovic, S., Vickery, S., \& Dröge, C. (2000). Quality-related action programs: Their impact on quality performance and firm performance. Decision Sciences, 31(4), 885-902.

De Toni, A., \& Nassimbeni, G. (2000). Just-in-time purchasing: An empirical study of operational practices, supplier development and performance. Omega, 28(6), 631651.

Dyer, J. H. (1996). Specialized supplier networks as a source of competitive advantage: Evidence from the auto industry. Strategic Management Journal, 17(4), 271-291.

Ellram, L. M., \& Krause, D. (2014). Robust supplier relationships: Key lessons from the economic downturn. Business Horizons, 57(2), 203-213.

Filippini, R., \& Forza, C. (2016). The impact of the just-in-time approach on production system performance: A survey of Italian industry. A review and outlook. Springer.

Fornell, C., \& Larcker, D. F. (1981). Evaluating structural equation models with unobservable variables and measurement error. Journal of Marketing Research, 18(1), $39-50$.

Galt, J., \& Dale, B. (1991). Supplier development: A British case study. International Journal of Purchasing and Materials Management, 27(1), 16-22.

Giunipero, L. C. (1990). Motivating and monitoring JIT supplier performance. Journal of Purchasing 83 Materials Management, 26(3), 19-25. 
Goffin, K., Lemke, F., \& Szwejczewski, M. (2006). An exploratory study of 'close' suppliermanufacturer relationships. Journal of Operations Management, 24(2), 189-209.

Graca, S. S., Barry, J. M., \& Doney, P. M. (2015). Performance outcomes of behavioral attributes in buyer-supplier relationships. Journal of Business $\&$ Industrial Marketing, $30(7), 805-816$.

Gunasekaran, A., \& Ngai, E. W. (2005). Build-to-order supply chain management: A literature review and framework for development. Journal of Operations Management, $23(5), 423-451$.

Hahn, C. K., Watts, C. A., \& Kim, K. Y. (1990). The supplier development program: A conceptual model. Journal of Purchasing and Materials Management, 26(2), 2-7.

Harmsen, H., Grunert, K. G., \& Bove, K. (2000). Company competencies as a network: The role of product development. Journal of Product Innovation Management: An International Publication of the Product Development and Management Association, $17(3), 194-207$.

Hartley, J. L., \& Choi, T. Y. (1996). Supplier development: Customers as a catalyst of process change. Business Horizons, 39(4), 37-44.

Hayes, R. H., \& Wheelwright, S. C. (1984). Restoring our competitive edge: Competing through manufacturing. Retrieved from http://id.lib.harvard.edu/alma/ 990011571530203941/catalog

Heide, J. B., \& John, G. (1990). Alliances in industrial purchasing: The determinants of joint action in buyer-supplier relationships. Journal of Marketing Research, 27(1), $24-36$.

Krause, D. R. (1997). Supplier development: Current practices and outcomes. International Journal of Purchasing and Materials Management, 33(1), 12-19.

Krause, D. R., \& Ellram, L. M. (1997). Critical elements of supplier development the buying-firm perspective. European Journal of Purchasing \& Supply Management, 3(1), 21-31.

Kulmala, H. I., Paranko, J., \& Uusi-Rauva, E. (2002). The role of cost management in network relationships. International Journal of Production Economics, 79(1), 33-43.

Lascelles, D. M., \& Dale, B. G. (1989). The buyer-supplier relationship in total quality management. Journal of Purchasing \& Materials Management, 25(2), 10-20.

Leong, L.-Y., Ooi, K.-B., Chong, A. Y.-L., \& Lin, B. (2011). Influence of individual characteristics, perceived usefulness and ease of use on mobile entertainment adoption. International Journal of Mobile Communications, 9(4), 359-382.

Li, S., Rao, S. S., Ragu-Nathan, T., \& Ragu-Nathan, B. (2005). Development and validation of a measurement instrument for studying supply chain management practices. Journal of Operations Management, 23(6), 618-641.

Li, W., Humphreys, P. K., Yeung, A. C., \& Cheng, T. E. (2007). The impact of specific supplier development efforts on buyer competitive advantage: An empirical model. International Journal of Production Economics, 106(1), 230-247.

Liker, J. K., \& Choi, T. Y. (2004). Building deep supplier relationships. Harvard Business Review, 82(12), 104-113.

Liu, L., Zhang, M., Hendry, L. C., Bu, M., \& Wang, S. (2018). Supplier development practices for sustainability: A multi-stakeholder perspective. Business Strategy and 
the Environment, 27(1), 100-116.

Low, K. Y. J., \& Ho, E. Y.-C. (2016). A knowledge-based theory of the multinational economic organization. Long Range Planning, 49(6), 641-647.

Monczka, R. M., Trent, R. J., \& Callahan, T. J. (1993). Supply base strategies to maximize supplier performance. International Journal of Physical Distribution 6 Logistics Management, 23(4), 42-54.

Narasimhan, R., \& Nair, A. (2005). The antecedent role of quality, information sharing and supply chain proximity on strategic alliance formation and performance. International Journal of Production Economics, 96 (3), 301-313.

Newman, R. G., \& Rhee, K. A. (1990). A case study of NUMMI and its suppliers. Journal of Purchasing \& Materials Management, 26(4), 15-21.

Nidumolu, S. R., \& Knotts, G. W. (1998). The effects of customizability and reusability on perceived process and competitive performance of software firms. MiS Quarterly, $105-137$.

Noordewier, T. G., John, G., \& Nevin, J. R. (1990). Performance outcomes of purchasing arrangements in industrial buyer-vendor relationships. Journal of Marketing, 54(4), $80-93$.

Peters, N. J., Hofstetter, J. S., \& Hoffmann, V. H. (2011). Institutional entrepreneurship capabilities for interorganizational sustainable supply chain strategies. The International Journal of Logistics Management, 22(1), 52-86.

Pulles, N. J., Veldman, J., \& Schiele, H. (2014). Identifying innovative suppliers in business networks: An empirical study. Industrial Marketing Management, 43(3), 409-418.

Reed, F. M., \& Walsh, K. (2002). Enhancing technological capability through supplier development: A study of the UK aerospace industry. IEEE Transactions on Engineering Management, 49(3), 231-242.

Robinson, C. J., \& Malhotra, M. K. (2005). Defining the concept of supply chain quality management and its relevance to academic and industrial practice. International Journal of Production Economics, 96(3), 315-337.

Routroy, S., \& Pradhan, S. K. (2014). Analyzing the performance of supplier development: a case study. International Journal of Productivity and Performance Management, 63(2), 209-233.

Saeki, Y., \& Horak, S. (2014). Trust and the cultivation of relation-specific skills. Evidence from a multinational automotive supplier in japan and germany. Management Decision, 52(8), 1433-1450.

Sakita, B. M. (2016). Containing opportunism in buyer-seller relationships: A case of tour operators and accommodation establishments in the Tanzania's tourism industry. Business Management Review, 19(1), 1-18.

Scannell, T. V., Vickery, S. K., \& Droge, C. L. (2000). Upstream supply chain management and competitive performance in the automotive supply industry. Journal of Business Logistics, 21(1), 23.

Schmalensee, R., Armstrong, M., Willig, R. D., \& Porter, R. H. (1989). Handbook of industrial organization. Elsevier.

Smeltzer, L. R. (1997). The meaning and origin of trust in buyer-supplier relationships. International Journal of Purchasing and Materials Management, 33(4), 40-48. 
Soares, A., Soltani, E., \& Liao, Y.-Y. (2017). The influence of supply chain quality management practices on quality performance: An empirical investigation. Supply Chain Management: An International Journal, 22(2), 122-144.

Swan, J. E., \& Nolan, J. J. (1985). Gaining customer trust: A conceptual guide for the salesperson. Journal of Personal Selling \& Sales Management, 5(2), 39-48.

Terpend, R., \& Krause, D. R. (2015). Competition or cooperation? Promoting supplier performance with incentives under varying conditions of dependence. Journal of Supply Chain Management, 51(4), 29-53.

Wagner, B. A., Fillis, I., \& Johansson, U. (2005). An exploratory study of SME local sourcing and supplier development in the grocery retail sector. International Journal of Retail \& Distribution Management, 33(10), 716-733.

Williamson, O. E. (2007). The economic institutions of capitalism. Firms, markets, relational contracting. Springer.

Womack, J. P., Womack, J. P., Jones, D. T., \& Roos, D. (1990). Machine that changed the world. Simon and Schuster. 